\title{
Enhancing the Zakat Framework of Maldives: A One Hundred Percent Muslim Country
}

\author{
Aishath Muneeza \\ International Centre for Education in Islamic Finance (INCEIF)
}

\section{ABSTRACT}

Maldives is a one hundred percent Muslim nation where the zakat administrative function is entrusted to a government ministry, the Ministry of Islamic Affairs (MIA), which manages zakat al maal and zakat al-fitr. Since June 1, 2016, MIA has delegated the task of collecting zakat to the Maldives Inland Revenue Authority (MIRA). Maldives presently has no law dealing with zakat, so the Islamic Training and Research Institute (IRTI) has proposed a set of zakat laws that could be adopted by the country. The objective of this qualitative research is to discuss the zakat framework proposed by IRTI. There is limited literature available on the zakat framework in Maldives, so it is anticipated that this study will become the starting point for further research on this topic.

Keywords: Maldives, Zakat administration, Zakat, Zakat framework

\section{INTRODUCTION}

Zakat, as the third pillar of Islam, is an obligation in respect of funds paid for a specific type of purpose and for specific categories. The term refers to a sum of money that Muslims who are of a sound mental and financial state must contribute in order to support specific groups of people according to eight categories as stated in the Quran in Surah At-Taubah verse 60 (Wahab \& Abdul Rahman, 2011; Yusuf \& Derus, 2013).

Muneeza (2017) outlined the history of zakat administration in Maldives as follows. The first office to deal with matters related to zakat was opened in 1983 under the leadership of Former President Uz. Maumoon Abdul Qayoom, with Sheikh Usman Abdulla appointed as the head of the office. During its early years of operation, around fifty Maldivian rufiyaa were collected annually as zakat on wealth. A Zakat Committee was formed to administer the technical zakat-related matters, with the mandate of this committee including the requirement to announce the nisab amount in Maldivian rufiyaa after considering the rate of silver. Discussions were undertaken in this committee with regard to determining the nisab limit in Maldivian rufiyaa, with an agreement being reached to utilize the comparative nisab in silver as the official amount of nisab in Maldivian rufiyaa. The price of silver on the world market is reviewed every six months, with the equivalent amount in Maldivian rufiyaa published as the nisab for Maldives. On November 11, 1993, the operation of the Zakat Office fell within the purview of the Ministry of Justice and Islamic Affairs. On November 6, 1996, zakat was 
brought under the Supreme Council for Islamic Affairs. The fi sabilillahi component of zakat distribution was administered via government ministries. The health component came to be administered by the Ministry of Health, while the education component was handled by the Ministry of Education. Educational assistance was provided to needy citizens, including, for example, textbooks and uniforms. In addition, debtors and the poor were assisted via the Zakat Office as cash benefits. In 2008, the Supreme Council for Religious Affairs was transformed into the Ministry of Islamic Affairs (MIA), with all mandates of the Zakat Office subsequently being transferred to the Ministry. The year 2012 saw the creation of an advisory body in the form of the Shariah Advisory Committee (SAC) comprising religious scholars. The SAC is mandated to advise both the zakat unit and zakat committee on matters pertaining to zakat in Islamic law and shariah opinion. In 2016, the operation carried out by MIA in the collection of Zakat-al-mal was handed over to the Maldives Inland Revenue Authority (MIRA). However, the MIA continues to collect Fitr Zakat (Maldives Inland Revenue Authority, 2016).

At present, Maldives has no law dealing with zakat, although the Islamic Training and Research Institute (IRTI) has proposed a set of zakat laws that could be adopted by the country. A workshop on the proposed zakat law for the Maldives was held in the Grand Islamic Center of Maldives on January 12, 2015, with IRTI meeting stakeholders and discussing the proposed zakat framework. The objective of this qualitative research is to discuss the IRTI's proposed zakat framework. Reflecting the fact that there is limited literature available about the zakat framework in Maldives, it is hoped that this research will act as a starting point for further research in this area.

\section{ZAKAT AL MAL COLLECTION AND ZAKAT FUND}

The Ministry of Islamic Affairs is the ministry in charge of religious matters, including zakat. MIRA was set up under the Tax Administration Act (Law No.3 of 2010) for the purpose of implementing tax-related laws and policies. Section 23 of the regulations on Business Profit Taxation 2011 provide an incentive to pay zakat by treating such payments as a deduction for tax purposes. The provision reads: "Payments made as zakat al-mal may be deducted in calculating a person's taxable profits provided that the person possesses a receipt that states that the zakat was paid to the relevant government authority" (Maldives Inland Revenue Authority, 2013).

Section 25 of the Public Finance Act 3/2006 states that a Trust Fund includes the Interest Suspense Account referred to in section 30 of this Law, in addition to any trust accounts that other Laws establish as part of the Trust Fund and trust accounts. A Trust Fund shall also include any trust accounts that are established from time to time for the following purposes: 1) the holding public of monies appropriated and passed in the budget for specific public purposes; 2) the holding of public monies by the State for or on behalf of any person that is not a government agency; 3) the temporary holding of public monies, money received as conditional grants, and money received in the form of a grant assistance, gift, or donation for a specific public purpose; 4) the temporary holding of public money received until such time as the purpose for which the money was 
received is identified; and 5) all public monies that have been appropriated and passed in a budget for a specific purpose of the trust account. A trust account must not be established without the written permission of the Minister and except for the purposes stated above.

Section 26 of the Public Finance Act 3/2006 states that when a trust account is established under this Law or another Law, a trust statement must be prepared for the account. Under this Law, "trust statement" refers to a document prepared and signed by the Minister containing the name of the trust account that is established, its purpose, the type and sum of money deposited in it, the expenses permitted from it, the person accountable for operating it, and all other details required to be maintained in relation to the account in accordance with the Public Finance Regulations. It is deemed to be the most authoritative document in respect of the account since it contains all of the official details relating to it. A trust statement that is consistent with section 30 of this Law must be prepared for an Interest Suspense Account, and all trust statements must be prepared in accordance with the Public Finance Regulations. The Minister, however, in accordance with the Public Finance Regulations, has the authority to amend a trust statement. Section 30 of the Public Finance Act 3/2006 states that as part of the Trust Fund there shall be an account called an "Interest Suspense Account." The public monies held in the Interest Suspense Account must be paid from it into a Public Fund or another trust account or accounts in accordance with the trust statement for the Interest Suspense Account, unless another Law states otherwise.

Section 27 of the Public Finance Act 3/2006 states that public monies must not be paid into a trust account except in accordance with the trust statement for the account. Section 28 of the Public Finance Act 3/2006 states that public monies must not be paid from a trust account except in accordance with the trust statement for the account, and a trust account must not be overdrawn. Public monies must not be paid from a trust account except in one of the following ways: 1) if the account was established under another Law, in accordance with that Law and the trust statement for that account, and 2) in the case of an Interest Suspense Account, in accordance with section 30 of this Law and the trust statement for that account, or, if another trust account, in accordance with the trust statement for that account.

Section 29 of the Public Finance Act 3/2006 deals with the closure of a trust account. The Minister has the authority to order a trust account to be closed if the purpose for which it was established has been fulfilled or if the Minister is of the view that this purpose will not be fulfilled. If the Minister orders a trust account to be closed, the balance of the public monies held in the account shall, after the payment of any liabilities due on it, be paid out in accordance with the provisions, if any, of the account's trust statement that deal with the closure of the account. If the trust statement does not provide for the same, such money shall be paid into the Consolidated Revenue Fund.

Muneeza (2017) states that according to the Trust Statement of the Zakat Fund, the trust account formed shall be called a zakat fund, with the zakat money received to be held in the Trust account until distributed in the format in schedule 1 of the Zakat Fund Trust Statement. Schedule 1 of the Zakat Fund Trust Statement gives the following 
categories that are eligible for the distribution of zakat funds: Masakeen "the destitute"; Fuqaraa - "the needy or poor"; Amil" Zakah - "alms collectors"; Fi sabi 'Lillah - "in the path of Allah SW; Gharimun - "people burdened with debt"; Ibn as'Sabil - "wayfarers"; Riqab - "people in bondage or slavery"; and Mu'Allaf - "those who have inclined toward Islam"). A zakat fund shall be governed in accordance with the Public Finance Regulations. Money deposited to the zakat fund shall comprise those monies paid as zakat by the citizens and corporations of Maldives. There is no ceiling with regard to the amount of money that may be deposited to the account as zakat money by individuals and corporations from the day the account is opened and until it is closed. All expenses made in accordance with schedule 2 of the Zakat Fund Trust Statement are authorized. According to schedule 2 of the Zakat Fund Trust Statement (first amendment effective from May 15, 2013), the following areas are authorized with respect to amounts paid from the account: the eight categories of people mentioned in the Quran 9:60 (Masakeen - "the destitute"; Fuqaraa - "the needy or poor"; Amil' Zakah - "alms collectors"; Fi sabi 'Lillah _ "in the path of Allah SW; Gharimun "people burdened with debt"; Ibn as'Sabil - "wayfarers"; Riqab - "people in bondage or slavery"; and Mu'Allaf "those who have inclined toward Islam"); the medical expenses of the poor; people inflicted with sudden calamities; bank commission incurred in the sending of zakat money; the spreading of Quranic knowledge and conducting Quran competition; the conducting of religious awareness activities; to build the human capital required for nation development and to educate people at local and international universities; expenses related to the creation and proofreading of religious materials; expenses incurred in conducting different educational courses related to religion; expenses incurred in Quran-related training, for teachers of Islam, and Imam training courses, undertaker, and other religious courses; expenses related to the conducting of Quran classes; to build worship places in schools, ablution facilities, and other services related to them; for expenses related to the peace and national security of the country and national-related matters; as the wages given to Taraweeh prayer imams during Ramadhan; as expenses incurred in the educating of children and people with special needs and spending on necessities for this category of people; expenses incurred in zakat money record-keeping and consultancy services; and the administrative expenses of the zakat fund and investment-related activities of the fund.

If, for any reason, the Zakat Trust Account is closed, any remaining balance at the time of closure shall be deposited to the consolidated revenue account. The Zakat Unit will prepare an annual report detailing the zakat monies received and disbursed, which shall be approved by the Zakat Committee. This report shall be prepared within one month of the end of the financial year. Within three months of the end of each Gregorian year, the zakat fund's annual report and financial statements from the previous year shall be gazetted in the National Gazette or daily newspapers, in addition to on the website of the MIA. The Zakat Trust Account shall be closed on a date determined by the Minister of Finance and Treasury following the receipt of a request to close the account from the MIA; alternatively, the Minister of Finance \& Treasury may 
order an account to be closed if he finds that the purpose for which the fund was established has not been achieved.

As per an announcement released on May 30, 2016 by MIRA, as stipulated in the Memorandum of Understanding signed between MIA and MIRA, zakat almal collected by MIA would, from June 1, 2016 onward, be collected by MIRA. Branches of MIRA and collection centers established on islands other than Malé would also collect zakat al-mal from June 1, 2016. Likewise, Island Councils would collect zakat al-mal from islands without an established MIRA branch or collection center. Individuals, partnerships, companies, and cooperative societies shall submit the designated form (MIRA 510) when paying zakat al-mal.

Table 1. Zakat al Mal Collection Made by MIRA

\begin{tabular}{|l|r|r|r|}
\hline \multicolumn{1}{|c|}{ Year } & Amount in USD & Amount in MVR & Total (MVR) \\
\hline 2018 (until May) & 515 & $21,623,870$ & $21,631,764$ \\
\hline 2017 & 12,128 & $63,150,889$ & $63,336,833$ \\
\hline 2016 & 3,004 & $35,853,470$ & $35,899,479$ \\
\hline
\end{tabular}

Source: Data compiled from the MIRA official website

In March 2018, the nisab for zakat al-mal was stated on the MIRA website as MVR 5,033.70. In June 2018, the MIRA's official Facebook page contained details of the MIRA Mobile Application, which can be used to conveniently make online payments via VaaruPay for vehicle fees, vessel fees, company annual fees, trade fees, and Zakat al-mal. When paying Zakat al-mal, it is only necessary to declare to MIRA the amount being paid as zakat.

\section{THE PROPOSED MODEL ZAKAT LAW FOR MALDIVES BY THE ISLAMIC RESEARCH \& TRAINING INSTITUTE, ISLAMIC DEVELOPMENT BANK}

The Zakat law for Maldives proposed by IRTI comprises six chapters. Chapter one deals with the general provisions, chapter two addresses zakat management infrastructure, while chapter three looks at zakat collection and disbursement. Chapter four deals with accountability and governance, chapter five outlines grievances, prohibitions, and penalties, and the sixth and final chapter is the closing chapter.

Article 1 of the proposed zakat law states that it shall be called the Zakat Act once it passes into law. Article 2 provides definitions for the following eight terms: 1) Zakat management is defined as the planning, implementation, and coordination of the collection, distribution, and utilization of zakat; 2) Zakat is defined as the part of property that must be given by a Muslim individual or a business entity to a charity that then distributes it to entitled recipients in accordance with Islamic law; 3) A muzakki is a Muslim or business entity obligated to pay zakat; 4) A mustahiq is a person entitled to receive zakat; 5) the Ministry of Islamic Affairs (MIA) is the government ministry responsible for all matters pertaining to the practice of Islam, including zakat management; 6) the Zakat Management Council (ZMC) is the national body for the management of zakat and other Islamic charity funds under the MIA; 7) a Baitul Maal is a fund comprising all zakat 
and non-zakat charity collections under the $\mathrm{ZMC}$; and 8) the Shariah Advisory Committee (SAC) is a body of Shariah experts with the function of providing Shariah legal opinion on matters pertaining to the management of zakat and sadaqa as periodically requested by the ZMC.

Article 3 of the proposed zakat law states that the aim of zakat management is to maximize the efficiency of zakat collection and the effectiveness of zakat utilization in order to optimize the benefits of zakat for public welfare and poverty alleviation. Article 4 states that zakat includes both zakat maal and zakat fitr. Zakat maal denotes zakat on property, with property referring to various forms of wealth, assets, output, and earnings. Zakatable assets and wealth include, but are not limited to, the following: gold, silver, and other precious metals; cash and other securities; and trade and business inventory. Zakatable output and earnings include, but are not limited to, those derived from the following sources: agriculture, horticulture, and forestry; livestock and fisheries; mining; revenues and services, and wealth extracted from the sea or excavated from underground. Zakat maal shall also be levied on zakatable assets, output, and any earnings over and above the amount stated, as determined by the $\mathrm{ZMC}$ in consultation with the SAC.

Article 5 of the proposed zakat law states that the payment of zakat is compulsory for individuals and business entities who own wealth, assets, output, and earnings that are zakatable as per the provisions of the proposed law and any subsequent rules and regulations formulated under the proposed law. Article 6 states that zakat maal shall be levied on a property that is under the clear and unambiguous ownership of an individual or business entity. If there is any debt inherent in a property subject to zakat, then such debt shall first be deducted from the property prior to computation of the zakat liability. Article 7 states that, notwithstanding the fact of ownership of property, a property shall not be zakatable under the following conditions: the property has no earning potential; the owner is not authorized to spend from the property; the property is in private or personal usage; and the property is being used as an evidentiary asset.

Article 8 states that where a property belongs to more than one person, zakat shall be determined on the basis of the pro-rata shares held by the respective individuals, while considering the property to be a jointly owned property (or severally owned property). Severally owned or jointly owned properties here include private businesses organized as partnerships and companies.

Article 9 states that property of the state, government organizations, and service administrations, city councils, atoll councils, and island councils, or similar property, are not zakatable, except when this is in the nature of investments. Zakatable property as given here shall include the property of all commercial ventures and companies in which the government may hold shares.

Article 10 states that property set aside especially for the benefit of the general public, or the property of nonprofit entities such as trust funds and nongovernment organizations, is not zakatable. Article 11 states that in order to be zakatable, the asset must have been in the ownership of a muzakki for at least one lunar year (hawl). In addition, to qualify as zakatable, the asset or output/earnings must exceed the nisab as 
defined by Islamic law. Zakat cannot be levied on any asset/output/earnings that have already been subjected to zakat during a given year.

Article 12 states that the terms, conditions, and methods of zakat calculation shall be in accordance with Islamic law and shall be provided by the "Rules of Zakat Calculation" as formulated by the ZMC in consultation with the SAC. Further provisions regarding the requirements and procedures for zakat calculation shall be determined by the ZMC. Provisions regarding the collection and distribution of zakat al-fitr shall be given in the "Rules of Zakat al-Fitr."

Article 13 states that MIA shall be the competent authority responsible for the administration of zakat on behalf of the State. A dedicated national body for zakat management, the Zakat Management Council (ZMC), shall be established and staffed within 14 days of this Act being promulgated by its publication in the official government gazette. The ZMC shall function as an integral and constituent body within the MIA. Article 14 states that the ZMC shall deposit all zakat and non-zakat charity funds in a dedicated account, to be called the Baitul Maal. The ZMC shall keep separate the zakat and non-zakat charity funds that are part of the Baitul Maal.

Article 15 states that in carrying out the tasks referred to in Article 13, the $\mathrm{ZMC}$ shall have the following functions: planning of the zakat management process, i.e. the collection, distribution, and utilization of zakat; implementation of the zakat management plan; monitoring and control of the zakat management process; and reporting of the operational performance of zakat management. The ZMC shall manage all non-zakat charity, with the exception of waqf. In carrying out its duties and functions, the ZMC will work with stakeholders in accordance with the provisions of the legislation.

Article 16 states that a Shariah Advisory Committee (SAC) shall be constituted by the MIA to advise the ZMC on Shariah issues pertaining to zakat management. Members of the SAC shall be appointed and dismissed by the MIA and shall comprise eminent scholars of Islamic law. The SAC shall periodically deliberate on issues relating to zakat management as referred by the $\mathrm{ZMC}$ and share its opinion with the ZMC. Further provisions on procedures for the administration of the SAC shall be elaborated by the MIA. The SAC shall be led by a chairman and a vice-chairman.

Article 17 states that each atoll council and city council, except Male', shall provide full support and coordination to the $\mathrm{ZMC}$ in order to receive zakat from the respective constituents, to distribute zakat, and to send a predetermined portion to ZMC. In addition, each island council shall coordinate in full with atoll councils on all issues with respect to zakat management. The portion of zakat to be sent to ZMC, as stated here, shall be determined by the MIA after considering the total wealth received from each local community, the number of people eligible to benefit from zakat, the degree of poverty among the people, and based on the information provided by the local councils regarding this issue. A dedicated member of staff shall be identified in every atoll council, island council, and city council, excluding Male', to represent the ZMC and ensure zakat management is carried out in accordance with the provisions of the Act and all relevant rules and regulations. The dedicated staff member, as stated here, 
shall be a civil service employee and shall be appointed following a process of consultation with the MIA and Civil Service Commission.

Article 18 states that a muzakki can undertake a self-calculation of their zakat obligation and may seek assistance from the $\mathrm{ZMC}$ for the purpose of determining this calculation. Article 19 states that the ZMC may appoint a bank, financial institution, or any other body to act as its agent for the collection, distribution, or both of zakat and nonzakat charity funds. Article 20 states that all zakat funds collected by the ZMC shall be placed in the Baitul Maal. Article 21 states that the ZMC can, in addition to zakat, collect sadaqa, infaq, tabarruat, and all non-zakat charity funds (except waqf), to be placed in the Baitul Maal. Article 22 states that zakat paid by muzakki to the ZMC shall be eligible for a full rebate in respect of income tax. Article 23 states that the ZMC shall provide each muzakki with a receipt as a record of their zakat payments, which shall be used by the muzakki to claim the rebate on their income tax payable. Article 24 states that further provisions relating to the enforcement and compliance mechanisms for zakat management shall be defined and elaborated by the MIA.

Article 25 states that zakat shall be distributed to mustahiq among the asnaf or persons considered to be eligible in accordance with Islamic law. Those persons considered to be eligible include the fuqara (poor), masakin (pauper), firiqab (under bondage), gharimun (heavily indebted), muallaftul qulubum (those whose hearts are inclined toward Islam), ibn-sabeel (traveler), amileen alaih (zakat officials), and fi-sabilillah (those in the path of Allah SWT).

Article 26 states that the specific criteria for the categorization of asnaf, along with definitions of the eligibility criteria to be used for recipients of zakat, shall be set out in the "Rules of Zakat Distribution," which shall be formulated by the ZMC in consultation with the SAC. The zakat allocation ratios for the various categories of eligible recipients shall be determined by the ZMC in light of the priorities and based on the principles of equity and justice.

Article 27 states that a muzakki has the right to distribute, in private, up to $20 \%$ of the amount that corresponds to his/her zakat liability. If a muzakki exercises his/her right in this manner and distributes any portion of zakat in private to those rightfully eligible to receive it, the details of the recipients shall be submitted to the $\mathrm{ZMC}$ or respective council office in the declaration provided in Appendix 1 of this Law.

Article 28 states that Zakat can be utilized for productive activities in order to alleviate poverty and improve quality of life. The utilization of zakat for productive activities as referred to in paragraph (1) shall be conducted after fulfilling the basic needs of the mustahiq. When zakat is utilized for productive activities, the poor person or other beneficiary must be made the owner of the zakat that is paid to him/her in conformity with the principle of tamleek, either on an individual or group basis. Further provisions for the productive utilization of zakat as mentioned here shall be determined by the ZMC.

Article 29 states that the ZMC shall strive to distribute the entire amount of zakat collected in a given year during that same year, with no amount carried forward to the next year. In exceptional cases, any surplus zakat in the Baitul Maal may be carried forward or invested in safe avenues for the short term. 
Article 30 states that the distribution and utilization of sadaqa funds shall be in accordance with Islamic law and shall consider the intention of the giver, if explicitly communicated. Article 31 states that surplus non-zakat funds in the Baitul Maal should be invested in safe avenues in a prudent manner. Guidelines for the prudent investment of surplus funds shall be formulated by the ZMC.

Article 32 states that, in order to perform their duties, the ZMC shall be financially supported as part of the State Budget and also zakat collection. The ZMC may thus utilize a small proportion of the zakat collected, not exceeding oneeighth, to cover the overall cost of collection or to incentivize the collection activity by entities acting as agents of the ZMC.

Article 33 states that in order to maintain the reliability of the process of zakat, the Auditor General's Office of the Maldives shall perform an annual audit of the $\mathrm{ZMC}$. In addition to the $\mathrm{ZMC}$, the respective councils and all other parties involved in zakat management shall extend their full cooperation and assistance to the representatives of the Auditor General's Office in relation to the performance of this audit. During the audit, if it is discovered that the proper documentation procedure has not been followed, the auditors shall have the right to hold those staff responsible accountable in order to investigate and clarify the details of the issue.

Article 34 states that the funds received in the form of zakat and nonzakat charity shall be deposited in the Baitul Maal as a separate specialized account with the Maldives Monetary Authority. The funds held here shall not be amalgamated with any other sources of government funds and shall not be deemed to be the property of the state.
The State is also unable to borrow the funds deposited here for fiscal purposes. Separate books shall be maintained for zakat and non-zakat funds, and all correspondence entered into during the process of mobilizing zakat into the Baitul Maal shall be in writing.

Article 35 states that the ZMC shall periodically compile a report on the zakat management, which must be submitted to the MIA on a regular basis. The compiled report on zakat management should be made available every quarter in both printed and electronic media. Further provisions on the reporting mechanism shall be determined by MIA.

Article 36 states that the public may participate in the advising and supervision of the $\mathrm{ZMC}$. The advising undertaken here shall be in order to increase the public awareness of giving charity through the ZMC and to provide suggestions for improving the performance of the ZMC. The type of supervision as outlined here takes the form of access to information about the management of zakat by ZMC and the delivery of information in case of irregularities in the management of zakat by the ZMC.

Article 37 states that if the muzakki discovers that the amount of zakat paid exceeds the obligatory amount, then the additional amount may be claimed back by submitting a request to the ZMC, accompanied by details of the calculations, within one month of having paid the money. If not submitted within one month, the muzakki shall cede the right to submit such a request at a later date. If the $\mathrm{ZMC}$ discovers that an amount of zakat received exceeds that of the requirement, the initial owner may be given the opportunity to outline in writing what could be done next, in response to 
them being notified of the excess, as per the rules to be established under this proposed law. If there is a valid claim for the subsequent recovery of any excess, this shall be carried out as per the procedure described in the rules, also considering the following year's zakat to be paid by the same muzakki.

Article 38 states that it is the responsibility of MIA to audit and confiscate any amount due as zakat but that has not been paid, with MIA having complete authority in the confiscation of such property. MIA has the right to obtain any assistance that may be required from the respective government administrations in order to complete the undertaking defined in para (1) of this Article. All State institutions shall provide their full cooperation in assisting MIA should such assistance be requested, in order to collect unpaid zakat funds.

Article 39 states that in the event of anybody having any grievance or complaint regarding zakat, this may be submitted to the ZMC or, via an island council, to the member of staff appointed as the representative of $\mathrm{ZMC}$ at the atoll council. Such complaints shall be submitted in writing, within 2 months of the occurrence of the issue, to the relevant authority. There shall be no fees applicable to any such complaints. Any issue regarding zakat will be sent to a court of law only if the complaints process described herein has been followed, by submitting the complaints to the relevant authority, and only if the issue is deemed to have been resolved unsatisfactorily. If the resolution of the complaint is deemed unsatisfactory, the matter may be lodged at a court of law within two months of the date of notification of the decision, or from the date on which the outcome is known, whichever is later. If, within such period, the matter has not been submitted, it shall be concluded that a full resolution has been achieved.

Article 40 states that every person is prohibited from owning, pledging, granting, selling, and/or diverting the zakat, sadaqa, and/or other non-zakat charity funds that are under their management. Article 41 states that it is forbidden to deliberately engage in the collection, distribution, or utilization of zakat without the prior consent and/or authorization of the ZMC. This prohibition does not apply to zakat distribution by a muzakki under Article 27 of this Act.

Article 42 states that any person who intentionally violates the provisions of Article 25 in the distribution of zakat shall be punished with imprisonment of 5 (five) years and/or a maximum fine of MVR 500000. Article 43 states that any person who willfully and unlawfully violates the provisions of Article 40 shall be punished with imprisonment of 5 (five) years and/or a maximum fine of MVR 500000. Article 44 states that any person who willfully and unlawfully violates the provisions of Article 41 shall be punished with imprisonment for a maximum of 1 (one) year and/or a maximum fine of MVR 50,000.

\section{RECOMMENDATIONS}

The stakeholders' perception of the proposed zakat framework is important. On January 12, 2015, a workshop on the proposed zakat law for Maldives was held at the Grand Islamic Center of Maldives, for IRTI to meet the stakeholders and discuss the proposed zakat framework. The stakeholders in this workshop included officials from the relevant ministries and members of the legal 
fraternity, public, and the media. The feedback received from the participants is summarized as follows:

1. The definition of Muzakki needs further clarification, especially where the zakatable entity is a Joint Venture with non-Muslim owners.

2. The definition of Baitul Mal in the context of Maldives generally means state treasury. Therefore, a different term should be used for the Zakat Fund.

3. Article $8-2$ of the proposed zakat law should include cooperatives in the list of zakatable entities.

4. The Membership number, qualification, power, and function of the SAC may be made part of the law and not left to be determined later by the ZMC.

5. The annual audit by the Auditor General should be of the Zakat Fund and the affairs of the ZMC.

6. The term "investigate" should be replaced by "inquire," and the term "staff" should be replaced by "party."

7. Zakat Fund financials should be in line with the applicable reporting and accounting standards.

8. The collection of Zakat function should be entrusted to MIRA (that can also act as an agent) in view of its capabilities, in order to avoid duplication.

9. The formulation of the ZMC needs to be articulated more clearly. It should include members of the community and civil service and not political appointees. Members should be qualified and should have no prior convictions or bankruptcies. The appointment mechanism, term duration, and break between consecutive terms all need to be spelled out. The models used by MIRA and Maldives Pension Administration Office may be followed.

10. Article 40: There is a need to clarify the term "Every Person."

11. Article 44: Punishment should be more severe, in line with other penalties.

12. Article 38: An additional paragraph should be added stating "MIA should have a dedicated internal audit function to provide objective and independent assurance and risk management, governance, and internal control of the ZMC."

13. The collection of zakat needs to be integrated with the IT system at MIRA.

\section{CONCLUSION}

Maldives, as a one hundred percent Muslim country, needs to enhance its national zakat framework. It is imperative to have a zakat law. The Zakat law proposed by IRTI is indeed a sophisticated draft law that the country needs to adopt as soon as possible in order to strengthen the zakat framework and boost the confidence of zakat payers in the zakat system. Zakat, as a pillar of Islam, needs to be handled in a transparent manner by the state to ensure the fulfillment of shariah objectives in terms of both its collection and disbursement. Adoption of the proposed zakat framework will definitely enable these objectives to be achieved.

\section{REFERENCES}

Latheef (2015). Govt's most hopeful minister, Dr. Shaheem resigns, Miadhu Daily [online] 
available from: http:/www.miadhu.mv/article/en /2269 [accessed 1 Feb 2017].

Maldives Inland Revenue (2016). Zakat al-mal to be collected by MIRA [online] available from:https://www.mira.gov.mv/e Newsletter/MIRApostArticles.as px? articleid $=15 \&$ block $=4$ [access ed 1 Feb 2017].

MIRA (2018). Monthly Revenue Collection, retrieved from https://www.mira.gov.mv/reports /May18.pdf

MIRA (2017). Monthly Revenue Collection, retrieved from https://www.mira.gov.mv/reports /December17R.pdf

MIRA (2016). Monthly Revenue Collection, retrieved from https://www.mira.gov.mv/reports /Dec2016 Final.pdf

MIRA (2016). Announcement, retrieved from

https:/www.mira.gov.mv/announ cement/Commencing_Collection of Zakat English.pdf

Muneeza, $\bar{A}$. (2017). Administration of zakat on wealth in Maldives. International Journal of Management and Applied Research, 4(1), 58-71. https://doi.org/10.18646/2056.41. 17-00

Public Finance Act 3/2006

Wahab, N. A., \& Abdul Rahman, A. R. (2011). A framework to analyse the efficiency and governance of zakat institutions. Journal of Islamic Accounting and Business Research, 2(1), 43-62. https://doi.org/10.1108/17590811 111129508

Yusuf, M. O., \& Derus, A. M. (2013). Measurement model of corporate zakat collection in Malaysia: A test of diffusion of innovation theory. Humanomics, 29(1), 6174.

https://doi.org/10.1108/08288661 311299321

Aishath Muneeza International Centre for Education in Islamic Finance (INCEIF) Malaysia muneeza.aishath@gmail.com 